\title{
Processes of Reflection in the Teaching and Learning Research Lab: Effects of Reflecting on Classroom Actions
}

\author{
Julia Peitz,", Nadine Baston ${ }^{1}$, Marius Harring ${ }^{1}$, Arnold Wittenhagen², Susanne Kram², Tobias Feldhoff ${ }^{1} \&$ Uwe \\ Schmidt $^{2}$ \\ ${ }^{1}$ Education and School Research at the Institute for Education Research, Johannes Gutenberg-University, Mainz, \\ Germany \\ ${ }^{2}$ Center for Quality Assurance and Development (ZQ), Johannes Gutenberg-University, Mainz, Germany \\ *Correspondence: Education and School Research at the Institute for Education Research, Johannes \\ Gutenberg-University, Germany, Mainz, Jakob-Welder-Weg 12, Mainz 55128, Germany. Tel: 49-(0)-6131-39-29312. \\ E-mail: j.peitz@uni-mainz.de
}

Received: April 4, 2021

doi:10.5430/jct.v10n2p14
Accepted: May 2, $2021 \quad$ Online Published: May 17, 2021

URL: https://doi.org/10.5430/jct.v10n2p14

\begin{abstract}
The ability to reflect on teaching is crucially important for the professionalization of trainee teachers. The fostering of reflection processes - by means of the systematic analysis of one's own and others' teaching from subject-specific, methodological, and educational science perspectives - plays a central role in a continuing and consecutive two-semester teacher training seminar concept at the University of Mainz.

This paper explores the different effects of reflection on teaching on the basis of a quasi-experimental pre-post test design. Additionally, it shows how systematic reflection on teaching affects the students' subjective experience of competence as well as the extent the seminar enables them to identify themes relevant for reflection. For example, the results of the comparison between two student groups working with different methodological approaches reveal that there are specific effects of opportunities for reflection on teaching. It was found that the students in both groups rated the relevance of self-reflection for their own later work as very high and felt much more confident in dealing with external video material. Moreover, the students in the intervention group appear to be increasingly capable of analysing teaching and learning processes in a more nuanced and systematic way based on theory and criteria; they are also more skilled at identifying reflection-relevant situations from various perspectives. As a consequence, it becomes clear that reflection on one's own and others' teacher actions must be integrated more strongly and consequently into teacher training in order to advance the development of one's own professionalisation and to make the best possible use of the associated potential.
\end{abstract}

Keywords: teacher training, reflection, professionalization, Teaching and Learning Lab, video analysis, one's own and others' actions in the classroom

\section{Introduction}

Processes of reflection are inseparably linked to processes of professionalization. Reflection is an act of observing something from a different perspective in which one's accustomed stance, attitude, and point of view is questioned or challenged by means of a deliberate shift of perspective without bias as to the expected result (cf. Tulodziecki, Herzig, \& Blömeke, 2017). This ability is regarded as the central intermediary between knowledge, skill, and experience (Artmann, Herzmann, Hoffmann, \& Proske, 2013, p. 134). The ability to engage in professional reflection has an emergence function in the development of professional competencies. Thus, the ability to reflect on one's own and others' actions in school and teaching contexts is a fundamental prerequisite for establishing and developing teachers' professional competencies (von Felten, 2005; Plöger, 2006). The call for deliberate and explicit fostering of reflection processes right from the earliest phase of teacher training (Hoffart \& Helmerich, 2017) arises, inter alia, from the central importance of the reflective faculty in teacher training.

This is the point of departure for the teacher training quality campaign at the University of Mainz. The goal of the 
project is to systematically give students a deeper understanding of teaching and learning processes in the first phase (Note 1) of teacher training and to develop options for action in practical teaching situations through joint reflection on teaching. This is achieved within the framework of Teaching and Learning Labs (TLLs), which are available for the subjects of English, History, Catholic Religious Education, Music, Physics, and Romance Languages(Note 2) and which are closely linked with courses in educational science. In the TLLs, students develop teaching units which are later tested and videotaped under classroom conditions. Subsequently, the students systematically analyse and reflect on the material. The basic dimensions of good teaching, especially cognitive activation(Note 3 ) - the stimulation of a deeper examination of the subject (Klieme, Lipowski, Rakoczy, \& Ratzka, 2006) and the fundamentals of observing and analysing teaching practices provide the theoretical and methodological framework for the courses.

On the basis of a formative evaluation of the TLLs, this paper discusses empirical findings that systematically place the focus on the different effects of reflecting on one's own teaching and that of others. We will show how these two forms of reflection help to enhance appreciation of the relevance of reflection as a whole and to increase future willingness to continue reflecting on teaching practices. Additionally, we explore the ways in which sessions of reflecting on teaching contribute to the subjective perception of competency. Finally, we analyse the extent to which they increase the participants' ability to identify topics of reflection that are relevant to professionalization.

\section{Theoretical Background - Material Studied}

Reflective competence is taken to be an essential component of professionalism (Note 4) and the definition thereof (Bromme \& Haag, 2008; Roters, 2012) with which teacher trainees link the academic knowledge acquired from their course work with the skills they develop in situations such as practical training during internships. More specifically, therefore, reflective competence consists of the ability to relate theoretical and practical knowledge to each other and thereby achieve a reflective detachment from one's own professional work (cf. Meyer, 2003, p. 101). It is defined as the competence of reviewing and explicitly justifying one's own actions and decisions in the context of a pedagogical situation in order to consciously learn from them and set in motion an educational process that fosters personality development (cf. Abels, 2011, p. 126).

Notwithstanding this, however, reflection cannot be described as a coherent, conclusively defined, and universally valid concept (Bengtsson, 2003; Fat'hi \& Behzadpour, 2011). Rather, it is primarily a catch phrase for diverse and different approaches (Feindt, 2007, p. 23) and is articulated by means of varying nuances, such as reflective thinking, critical reflection, critical thinking, participatory reflexivity, or reflective practitioner (Loughran, 2002, p. 33).

The theoretical basis of this paper is the model of the reflective practitioner. Since this approach explicitly relates the practice of reflection to one's own actions, whereas, other models regard the relationship between reflection as action as more of an implicit process. Following Donald Schön (1983), we examine reflection in the concept of the reflective practitioner not as an isolated thought process, but as one that is directly related to (reflective) action. In Schön's view, reflection can help in learning more about one's own actions and improving them (Helmke, 2012, p. 116). Problems one faces in one's profession should be explored while evaluating different interpretations and altering one's actions accordingly. The aim, therefore, is to specifically improve one's own actions and to develop additional competences as well as a positive, open attitude towards one's professional skills (Leitch \& Day, 2000). This model of reflective practice (Schön 1983) is divided into three types of action: reflection-for-action, reflection-in-action, and reflection-on-action. Reflection-for-action refers to the planning phase of professional situations in which the prerequisites for professional actions are analysed in advance. Reflection-in-action is characterized by the ability to reflect during an action and professionally adapt the action to the prevailing conditions. This type is divided into six phases: (1) A problematic situation arises, (2) the problem is defined, the definition of the problem is (3) implemented and (4) experimentally verified, (5) a hypothetical definition of the given situation is formulated, and finally (6) the definition of the problem is evaluated (Schön, 1983). The third type, reflection-on-action, describes reflection after a completed action as a complex process that is detached from the practical situation. In addition to the specific reframing of a situation from the perspective of different actors, it also includes the formulation of alternative actions. In this model, professional actions develop through the interaction of all three types (Roters, 2012). Reflection can take place in different forms and on different levels that may result in action and could be internal, like the change of the own plans or external, like the involvement of others in developing alternative courses of action. For example, Mühlhausen (2006) distinguishes between closed reflection guided by previously defined criteria and open reflection guided by self-chosen criteria. These forms of reflection may be applied on different levels. Reflection-on-action can be performed independently, in cooperation with peers, in the team, or in the form of reflecting on others' teaching. In the case of reflection-in-action, there is a general 
distinction to be drawn between processes affecting one's own person, classroom actions, and interaction with others (micro level); processes that are not part of everyday activities but that affect everyday work, such as communicating with colleagues or parents (meso level); and processes that may affect higher levels, such as cooperation with authorities (macro level). Reflection can be carried out orally, in writing (using a variety of aids such as questionnaires or portfolios), or by evaluating one's own actions through audio and video recordings (Note 5). Observation is regarded as an important step towards constructive reflection (van Es \& Sherin, 2008).

Thus, professional reflection on teaching calls for the ability to observe teaching and learning processes with a selected focus in mind and requires a systematically structured and designed reflection process in the course of which links must constantly be drawn and relationships identified between reflected actions and one's own teaching actions. This is the case because reflection on teaching within the project has the purpose of getting students to improve and adapt their teaching practice based on the results of their reflection.

\section{State of Empirical Research - Area Description}

Students have a consistently favourable perception of opportunities for reflection during teacher training and generally regard invitations to reflect on their teaching practice as useful (Hoffart, 2015; Herzmann, Artmann, \& Wichelmann, 2017). Because students often find that they remember situations differently from how they occurred, they perceive reflection as a fascinating process that offers them added value (Hoffart \& Helmerich, 2017). However, empirically recording reflective competence presents an enormous challenge. In order to represent reflective competence with all its complexity, both the action and the attitudes underlying the action must be taken into account (Copeland, Birmingham, de la Cruz, \& Lewin, 1993). Over the past three decades, a number of intervention and evaluation studies have sought to do this (Day, 1993; Hatton \& Smith, 1995; Seidel \& Prenzel, 2007; Brouër \& Gläser-Zikuda, 2010; Leonhard, 2013; Vogel, 2013; Santagata \& Yeh, 2014; Hoffart \& Helmerich, 2017; Wehner \& Weber, 2018). For example, Day (1993) shows that learners operate at different levels of reflective competence depending on the context and situation. Based on this finding it can be assumed that reflective competence is fundamentally teachable and learnable by training. Zeichner \& Liston (1987) examined the relationship between a teacher's moral values and his or her reflectiveness. Prior to the study, a special teacher training programme enabled participants to reflect on their pedagogical attitudes, independent learning skills, and motivation to engage with issues of educational policy. Possible development trajectories were measured using the Reflective Teaching Index (RTI). The results of the study show that students primarily attain the subject-related (63.2\%) and reasonable (24.9\%) reflective levels. Only $0.6 \%$ of the discourses achieved a critically reflective level (Zeichner \& Liston, 1985, p. 165). Additionally, the study did not identify either an increase in reflective competence to a higher level or a change in attitude to teaching and the role of the teacher. These findings are largely corroborated by other intervention studies (e.g., Leonhard, 2013; Wehner \& Weber, 2018) as well as by a variety of different data sources (learning diaries, homework, log books, test vignettes). In particular, attaining the highest level of reflective competence distinguished by breadth and depth of reflection (Vogel, 2013) - remains a difficult task.

One prominent approach to promoting reflective skills which, because of its inherent potentials, has been used since the 2000s is video-based reflection (Note 6), for which numerous studies that use different formats of videos and deal with different subjects have been published (Sato, Akita, \& Iwawaka, 1993; Louden, Wallace, \& Groves, 2001; Sherin \& Han, 2004; Krull, Oras, \& Sisak, 2007; Borko, Jacobs, Eiteljorg, \& Pittman, 2008; Schwindt, 2008; Leijen, Lam, Wildschut, Simons, \& Robert-Jan, 2009; Seidel, Blomberg, \& Stürmer, 2010; Snyder, 2011; König, 2015; Kramer, König, Kaiser, Ligtvoet, \& Blömeke, 2017; Gabriel-Busse, Groß-Mlynek, Feldhoff \& Harring, 2020). However, the current state of knowledge remains rather unclear. Thus, video analysis studies involving expert-novice comparisons (Sato et al., 1993; Krull et al., 2007; Gabriel-Busse et al., 2020) point to quantitative and qualitative differences in the participants' reflections. The novices first receive practice sessions for systematic observation and theory-based assessment within the framework of teaching units with instructional videos. The reflections of the experts are significantly more detailed, more substantiated and more critically reflective, while the reflections of the novices more frequently contain superficial descriptions. The difference, thus, lies in higher perceptual competence and the concomitant ability to observe learning and teaching processes much more thoroughly. Studies involving video-based reflection (e.g., Star \& Strickland, 2008; Santaga \& Guarino, 2011; Snyder, 2011) have shown positive effects in terms of teachers adapting their teaching behaviour and improving their situation-specific skills to optimize their teaching. However, comparative studies of videos and the use of transcripts (e.g., Kramer et al., 2017; König, 2015) suggest that videos are not a magic bullet. These studies do not point to significant differences in efficacy between the two media for the development of situation-specific classroom management skills, hence the actual 
effect of videos remains unclear (Kramer et al., 2017; see also König, 2015). The study also points out that students who work with videos differ from those using transcripts in their enjoyment of the seminar curriculum and in their cognitive activation. Video work is regarded as more cognitively activating as well as more interesting. However, it remains unclear to what extent the stated effects differ when using one's own vs. others' teaching videos, since systematic investigations on the effects of these two modes of reflection remain a desideratum.

\section{Course Concept - Links between Educational Sciences and Teaching Methodologies}

The TLLs at the University of Mainz focus on the (continuing) professionalization of students with an emphasis on promoting processes of reflection on teaching practice. To facilitate this, students systematically reflect on videos of their own teaching and that of their classmates in order to establish the effects of these two forms of reflection. This format is supported by a conceptual implementation of Reflective Practice (Schön, 1983) in the Master of Education program for a total of two semesters, in the context of a continuing and consecutive seminar concept, by combining courses in educational science and teaching methodology courses both at the organizational level and that of content and methodology.

In the beginning, educational science students attend the first part of a research workshop focusing on the basics of good teaching - effective classroom management, a social climate conducive to learning, and cognitive activation (Klieme et al., 2006). In addition to emphasising the characteristics and effects of exercise formats that produce cognitive activation, the workshop also refers to the content of the teaching methodology courses taken concurrently by the students. These courses are directly based on the knowledge and skills imparted by the educational sciences courses, developing the subject-specific aspects of cognitive activation and translating them into each subject's teaching methodology. These links not only develop the students' awareness of the general methodological prerequisites and preconditions for achieving cognitive activation in teaching. Rather they draw their attention to aspects specific to each subject during the preparation of appropriate exercise formats. This creates a basis on which students can independently develop these subject-specific exercises while also constantly engaging in critical reflection on them and systematically improving them during the conception process using the characteristics and necessary preconditions that were developed previously (reflection-for-action). During the development process, the student workgroups are supported by a tandem consisting of two individuals, a representative of the educational sciences and a representative of each subject's teaching methodology. This creates opportunities for multi-perspective discussions between educators and learners that have proved to be constructive and profitable for fostering and intensifying student's reflection during the planning phase. At the same time, the first part of the educational science course focuses on the analysis of others' teaching videos in order to allow students to immediately analyse aspects of cognitive activation in practical teaching and simultaneously familiarize themselves with the method of indicator-based video analysis (reflection-on-action of others' teaching practice).

After the joint concept development phase, students have the opportunity to apply their new knowledge in practice by using their newly developed exercises within the TLL and testing them for at least two school hours under teaching conditions with school students at cooperating schools, at the university, or at out-of-school learning centres. After having their awareness heightened by analysing teaching videos in their seminars, students are now explicitly challenged to critically and reflectively adapt their real-life professional teaching practice to the teaching situations they encounter (reflection-in-action). This practical implementation is visibly and completely (Note 7) recorded on video and thereby made available for further studies at the university. By the use of at least four to six dome cameras on walls and on tripods - depending on the initial situation such as the room sizes - that are located in the front, the back and on the side of seated students a multi-perspective insight into the interaction taking place in the classroom is possible. The students' reflections are taken up in the methodology seminars and critically discussed on the basis of videos of the real-life teaching settings, so that their own assessments and their actual adaptive performance become tangible for the students and can be reconstructed in cooperation with the methodology lecturers.

In the following semester, systematic reflection on one's own teaching takes place in the second part of the educational sciences workshop (reflection-on-action of one's own teaching practice). The recorded videos serve as the basis for reflection for testing the exercise formats and one's own teaching strategies. Viewing the teaching videos in small workgroups in a setting with no immediate pressure of action (Kahlau \& Tietjen, 2018), students begin by identifying situations relevant for reflection (reflection-on-action). In the explorative learning process that follows, they independently formulate research questions that relate to the effects of their own teaching and to the testing of the exercise formats with school students under classroom conditions and that systematically focus on cognitive activation in a critically reflective manner (Reinmann, 2015). Students develop their own low-inferent 
category systems and high-inferent rating systems, which are used for systematic, criteria-guided reflection in order to gain awareness of the conditions and circumstances of their actions. Finally, the insights acquired from the video-based reflections are summarized with the goal of formulating specific alternative actions with which to adapt and improve the students' actions in the classroom.

\section{Research Questions and Methodology}

The data presented here are based on a formative evaluation of the TLLs, which is regularly conducted by the Centre for Quality Assurance and Development in the form of a pre-post design. This survey includes a total of 45 Master of Education students in the 2018/19 winter semester and the 2019 summer semester who were divided into an intervention group and a comparison group. The 20 students in the intervention group took the cooperative video-based course, while the 25 students in the comparison group attended research workshop with an alternative methodological concept (e.g., own classroom observation of a teacher or verbal transcript-based methods). The average age of the students was 24.5 years; 29 were female, 15 were male, and one declined to state their gender. The majority of the students were in the third semester of their master's programme. The data were collected by means of a questionnaire developed for the purpose of the evaluation. The questionnaire contained a total of 73 items (Note 8) with seven-point Likert scales (e.g., from "strongly disagree" to "strongly agree" and from "not applicable at all" to "fully applicable") and three with open answer formats. This analysis focuses particularly on the educational studies aspect of reflection-on-action, which is fostered on the basis of the teaching videos. These reflection units are studied using items that seek to discover participants' assessment of the relevance and usefulness of reflection, their intention to continue systematically reflecting on teaching in the future, and their subjective experience of competence. The aim is to identify the different contributions of the two forms and modes of reflection in these areas. The research questions on which this aim of inquiry is based are the following:

(1) Are there differences between the groups in the effects of reflection on teaching with respect to

a) the perceived relevance of systematic reflection on teaching;

b) the intention to systematically reflect on teaching in the future;

c) the experience of competence in systematic reflection (reflection-on-action);

(2) To what extent do the groups differ with respect to identifying themes that are relevant for reflection?

It is assumed that the group that works with their own teaching videos recognises the relevance of reflection more strongly, since they refer directly to their own practice when reflecting. Therefore, there is also the assumption that through the reflective examination of their own actions, they are more likely to recognise the added value of systematically reflecting on teaching in the future. Since these students also deal with teaching quality - with a focus on cognitive activation - in the seminar, it can be assumed that they observe and reflect on teaching in a more differentiated way based on the theory of cognitive activation they have learned.

Possible differences between the student groups are highlighted primarily by comparing mean values after testing for homogeneity of variance and for significance (T-test) (1a). Using correlation calculations with respective effect sizes (Pearson and Cramers V) as well as linear regression analyses, the different modes of action of the students' reflection processes on their own teaching and that of their classmates are illustrated in the context of the focus of each analysis.

A scale of six items (Note 9) emerges from an explorative factor analysis with satisfactory KMO values of $>0.7$. This scale, which addresses the general intention of continuing to engage in systematic reflection on teaching, is the focus of the analyses of the second research question (1b). The third research question (1c) focuses on assessments of competence using reflection-on-action. These assessments are recorded using three-item scales (Note 10) referring to one's own and others' teaching. The scaled values of reflection-on-action result from a previously performed factor analysis and exhibit satisfactory KMO values of $>0.7$. The fourth research question (2) is based on the open item "Imagine you are helping a future teacher evaluate their teaching because they have never done this before. What questions would you ask them to facilitate appropriately systematic reflection on their teaching?" The purpose of this item is to get the students to state at least five possible areas of reflection. Evaluation is performed using a deductive-inductively developed category system (Mayring 2015) in which the students' formulated themes are first used to compile specific theme complexes and these complexes are subsequently associated with appropriate categories. At first, the coding scheme was developed by two reviewers before a second set of reviewers analysed the 
material. The intercoder agreement of the two coders of the second set is satisfactory at 86.2 (Wirtz \& Casper, 2002).

\section{Results}

\section{1 (1a) Perceived Relevance of Systematic Reflection on Teaching}

Overall, the students in the intervention group ascribe greater importance to reflecting on their teaching activities $(\mathrm{MV}=5.30)$ after attending the seminar than the comparison group $(\mathrm{MV}=4.80)$. To explain this difference, regression analyses were performed in both groups (Table 1). In the intervention group, perception of the relevance of systematic reflection depends on the ascription of meaning to the reflection of own $\left(\beta=.743^{* *}\right)$ and others' actions in the classroom $\left(\beta=.414^{* *}\right)$. In other words, whether systematic reflection on teaching is perceived as relevant depends on the extent to which reflecting on own or others' actions in the classroom is recognized as being meaningful. The students in this group ascribe significantly higher meaning to reflecting on own teaching $(\mathrm{MV}=$ $5.45)$ and others' teaching ( $M V=4.70)$. In contrast, the comparison group ascribes lower meaning in both contexts: $\mathrm{MV}=5.15$ for own and $\mathrm{MV}=4.50$ for others' teaching. Additionally, the only factor with a positive impact on perceived relevance in this group is perceived meaningfulness of reflection on own teaching $\left(\beta=.947^{* * *}\right)$. Thus, the students in the intervention group not only recognize the meaningfulness of reflecting on their own teaching during the course of the seminar, but also exhibit an awareness of the meaningfulness of reflecting on others' teaching. Finally, this recognition of meaningfulness of both forms of reflection has a positive influence, with powerful effects on the perception of the relevance of systematic reflection on teaching.

Table 1. Linear regression Model for perceived Relevance of Reflection for Later Teaching Activity (intervention group $\mathrm{t} 2$, comparison group $\mathrm{t} 2$ )

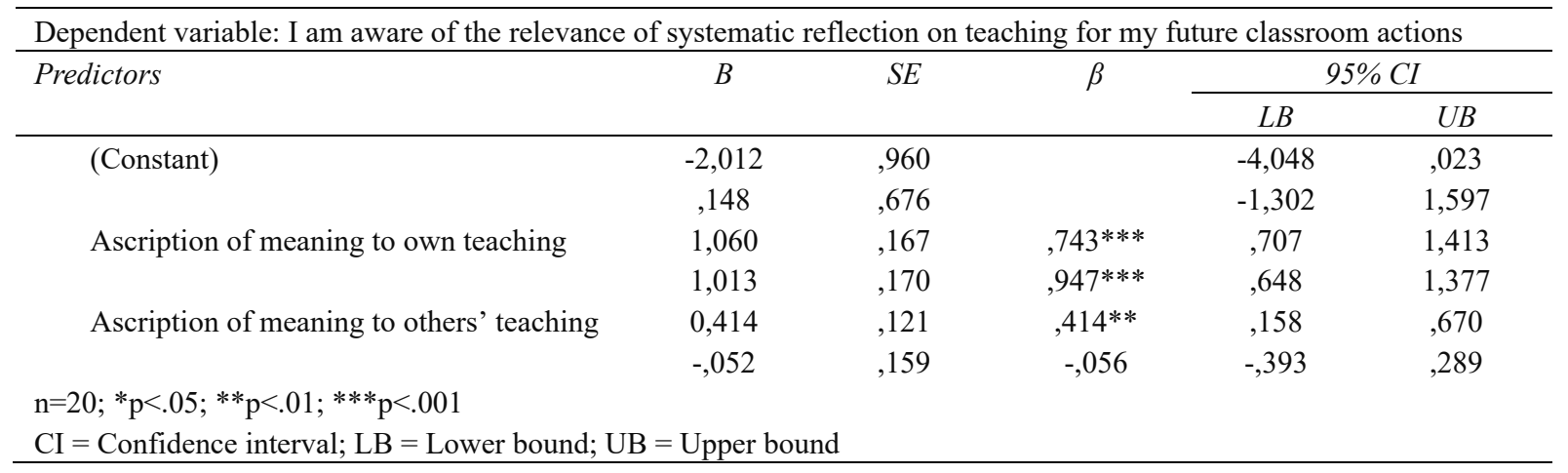

\section{2 (1b) The Future Intention to Systematically Reflect on Teaching}

With respect to the objective of continuing to systematically reflect on teaching in the future, the comparison of mean values shows that the students in the intervention group are significantly $(p=.559)$ more likely $(\mathrm{MV}=5.06)$ to have the intention of continuing systematic reflection than the students in the comparison group $(\mathrm{MV}=4.95)$. One interesting difference between the groups emerges from the analysis of relevant factors that affect this objective (Table 2). In the intervention group, the intention is more strongly influenced by the readiness to reflect on others' actions $\left(\beta=.675^{* * *}\right)$ than on own actions $\left(\beta=.524^{* * *}\right)$ in the classroom. The opposite is true of students in the comparison group, whose intention to continue reflection is more strongly influenced by the readiness to reflect on own actions $\left(\beta=.622^{* * *}\right)$ than on others' actions $\left(\beta=.495^{* * *}\right)$ in the classroom. A nuanced examination reveals indications that the students' future intentions are related to differences in the perceived usefulness of the two forms of reflection. While no statistically significant correlations can be identified in the comparison group after attending the seminar, the intervention group exhibits significant correlations with respect to reflection on teaching (Table 3). These students thus recognize benefits in reflecting both on their own teaching and on that of their classmates; these perceived benefits, moreover, are closely connected with the intention to continue systematically reflecting on teaching in the future. However, the perception of the benefits of each form of reflection is nuanced in character: In the context of reflecting on others' teaching, students primarily perceive the benefits of systematic observation (Person 0.623**, Cramers V $=0.571$ ) and evaluation (Person 0.448*, Cramers V $=0.493$ ), while they regard reflection on their own actions as beneficial mainly for adapting their own actions (Person 0.668*, Cramers $\mathrm{V}=$ 0.620). Thus, this student group recognizes the future usefulness of both types of reflection, but ascribes different 
functions to each of them: while the relevance of reflecting on others' teaching lies in observation and assessment, that of reflecting on own teaching lies in the transfer of actions - i.e., in optimising one's own actions in the classroom. These specific ascriptions of usefulness to reflecting on others' and own teaching significantly influence this student group's readiness to continue systematically reflecting on teaching in the future.

Table 2. Linear Regression Model for Future Intention to Systematically Reflect on Teaching (intervention group t2, comparison group $\mathrm{t} 2$ )

\begin{tabular}{|c|c|c|c|c|c|}
\hline \multicolumn{6}{|c|}{ Dependent variable: Future intention to systematically reflect on teaching } \\
\hline \multirow[t]{2}{*}{ Predictors } & \multirow[t]{2}{*}{$B$} & \multirow[t]{2}{*}{$S E$} & \multirow[t]{2}{*}{$\beta$} & \multicolumn{2}{|c|}{$95 \% C I$} \\
\hline & & & & $L B$ & $U B$ \\
\hline \multirow[t]{2}{*}{ (Constant) } &,- 006 & 007 & &,- 022 & 010 \\
\hline &,- 009 & 020 & &,- 064 & ,046 \\
\hline \multirow[t]{2}{*}{ Willingness to reflect on own teaching } &, 501 & ,001 &, $524 * * *$ & ,498 &, 504 \\
\hline &, 501 & 002 &, $622 * * *$ & 497 & ,506 \\
\hline \multirow[t]{2}{*}{ Willingness to reflect on others' teaching } &, 500 & 001 &, $675 * * *$ & 489 & ,503 \\
\hline &, 500 & 001 &, $495 * * *$ & ,496 & ,504 \\
\hline \multicolumn{6}{|l|}{$\mathrm{n}=20 ; * \mathrm{p}<.05 ; * * \mathrm{p}<.01 ; * * * \mathrm{p}<.001$} \\
\hline \multicolumn{6}{|c|}{$\mathrm{CI}=$ Confidence interval; $\mathrm{LB}=$ Lower bound; $\mathrm{UB}=$ Upper bound } \\
\hline
\end{tabular}

Table 3. Correlation Analysis, Intervention Group t2 and Comparison Group t2

\begin{tabular}{|c|c|c|c|}
\hline & & \multicolumn{2}{|c|}{$\begin{array}{l}\text { I am aware of the relevance of } \\
\text { systematic reflection on teaching } \\
\text { for my future classroom actions }\end{array}$} \\
\hline & & $\begin{array}{l}\text { Intervention } \\
\text { group } \mathrm{t} 2\end{array}$ & $\begin{array}{l}\text { comparison } \\
\text { group t } 2\end{array}$ \\
\hline Objectives: & Correlation Pearson $\mathrm{t} 2$ & 0,266 & 0,072 \\
\hline I intend to: & Significance t 2 & 0,257 & 0,762 \\
\hline $\begin{array}{l}\text {... observe the effects of my future classroom actions } \\
\text { with professional detachment. }\end{array}$ & Cramers V t2 & 0,380 & 0,452 \\
\hline ... evaluate the effects of my future classroom actions & Correlation Pearson $\mathrm{t} 2$ & 0,377 & 0,194 \\
\hline \multirow[t]{2}{*}{ with professional detachment. } & Significance $\mathrm{t} 2$ & 0,102 & 0,427 \\
\hline & Cramers V t2 & 0,429 & 0,556 \\
\hline ...learn from my own classroom actions and adapt my & Correlation Pearson $\mathrm{t} 2$ & $0,668^{*}$ & 0,042 \\
\hline \multirow[t]{2}{*}{ performance in subsequent situations. } & Significance t2 & 0,001 & 0,865 \\
\hline & Cramers V t2 & 0,620 & 0,754 \\
\hline Objectives: & Correlation Pearson $\mathrm{t} 2$ & $0,623 * *$ & 0,141 \\
\hline I intend to: & Significance $\mathrm{t} 2$ & 0,006 & 0,564 \\
\hline $\begin{array}{l}\text {... observe the effects of others' classroom actions with } \\
\text { professional detachment. }\end{array}$ & Cramers V t2 & 0,571 & 0,428 \\
\hline ... evaluate the effects of others' classroom actions & Correlation Pearson $\mathrm{t} 2$ & $0,448 *$ & $-0,081$ \\
\hline with professional detachment. & Significance $\mathrm{t} 2$ & 0,047 & 0,735 \\
\hline \multirow{4}{*}{$\begin{array}{l}\text {... learn from others' classroom actions and transfer } \\
\text { these insights to future action situations. }\end{array}$} & Cramers V t2 & 0,493 & 0,345 \\
\hline & Correlation Pearson $\mathrm{t} 2$ & 0,371 & 0,022 \\
\hline & Significance $\mathrm{t} 2$ & 0,107 & 0,930 \\
\hline & Cramers V t2 & 0,492 & 0,448 \\
\hline
\end{tabular}




\section{3 (1C) Experience of Competence (reflection-on-action)}

After attending the seminar, students in the intervention group give higher scores for subjective experience of competence ( $\mathrm{MV}=4.47)$ than the comparison group $(\mathrm{MV}=3.65)$, but this difference is not significant. It is conspicuous, however, that both student groups feel more confident about engaging reflectively with others' teaching $\left(\mathrm{MV}_{\mathrm{IG}}=4.53 ; \mathrm{MV}_{\mathrm{CG}}=4.08\right)$ than with their own $\left(\mathrm{MV}_{\mathrm{IG}}=4.42 ; \mathrm{MV}_{\mathrm{CG}}=4.01\right)$.

\section{4 (2) Identification of Themes Relevant for Reflection}

When it comes to identifying subjects relevant for reflection, the intervention group differs from the comparison group in exhibiting a broad spectrum of reflection subjects (Table 4) that is characterized by nuanced and well-founded questions. While the comparison group still has numerous questions about the personal feelings of the teachers after attending the seminar, the intervention group predominantly focuses on theoretical issues. Additionally, this group's topics for reflection also reference the emphases of the subject methodologies taught in concurrently running courses rather than confining themselves exclusively to topics of general educational methodology. The intervention group also engages in significantly more reflection from multiple different perspectives. After attending the seminar, the students' priorities shift depending on the level. Thus, the intervention group achieves a balanced relationship between the teacher's and students' perspectives. For example, before attending the seminar, the students' perspective was dominant on the level of reflection about learning, while the teacher's perspective was dominant on the level of reflection about the subject. In the comparison group, in contrast, the teacher's perspective remained dominant even after attending the seminar. As a consequence, the students in the intervention group are capable of assessing teaching both from the students' and the teacher's perspective after attending the seminar.

Table 4. Identification of Topics Relevant for Reflection, $\mathrm{T} 0$ and $\mathrm{T} 2$ Separately

\begin{tabular}{|c|c|c|c|c|}
\hline & & $\begin{array}{l}\text { Comparison group } \\
(\mathrm{n}=\mathbf{2 5})\end{array}$ & $\begin{array}{l}\text { Intervention group } \\
(\mathrm{n}=\mathbf{2 0})\end{array}$ & Total \\
\hline \multirow[t]{2}{*}{ Supercategories } & \multirow[t]{4}{*}{ Subcategory } & Frequency & Frequency & \\
\hline & & $\mathrm{T} 0 / \mathrm{T} 2$ & $\mathrm{~T} 0 / \mathrm{T} 2$ & \\
\hline Future actions & & $2 / 0$ & $1 / 3$ & 6 \\
\hline $\begin{array}{l}\text { Questions about } \\
\text { perceptions and } \\
\text { positive/negative } \\
\text { evaluations }\end{array}$ & & $12 / 16$ & $16 / 10$ & 54 \\
\hline \multirow[t]{18}{*}{ Reflecting on learning } & Cognitive activation & $1 / 6$ & $9 / 12$ & 28 \\
\hline & Comprehension & $2 / 2$ & $0 / 1$ & 5 \\
\hline & Learning climate & $2 / 1$ & $5 / 2$ & 10 \\
\hline & Learning types & $0 / 0$ & $1 / 0$ & 1 \\
\hline & $\begin{array}{l}\text { Methodological concepts } \\
\text { (e.g,. deeper learning, } \\
\text { problem orientation) }\end{array}$ & $0 / 0$ & $1 / 7$ & 8 \\
\hline & Motivation and interest & $0 / 5$ & $2 / 5$ & 12 \\
\hline & Performance evaluation & $0 / 0$ & $1 / 0$ & 1 \\
\hline & Quality of contributions & $0 / 0$ & $3 / 0$ & 3 \\
\hline & $\begin{array}{l}\text { Student behaviour and } \\
\text { attention }\end{array}$ & $1 / 1$ & $1 / 1$ & 4 \\
\hline & Student participation & $6 / 3$ & $8 / 5$ & 22 \\
\hline & Working independently & $0 / 0$ & $2 / 1$ & 3 \\
\hline & Total & $12 / 18$ & $33 / 34$ & 97 \\
\hline & $\begin{array}{l}\text { of which teacher's } \\
\text { perspective }\end{array}$ & $6 / 19$ & $1 / 15$ & 41 \\
\hline & $\begin{array}{l}\text { of which student's } \\
\text { perspective }\end{array}$ & $4 / 7$ & $29 / 14$ & 54 \\
\hline & Activity-oriented & $0 / 1$ & $0 / 0$ & 1 \\
\hline & Clarity & $4 / 2$ & $2 / 4$ & 12 \\
\hline & Competences & $0 / 1$ & $1 / 0$ & 2 \\
\hline & Complexity & $1 / 0$ & $2 / 1$ & 4 \\
\hline
\end{tabular}




\begin{tabular}{|c|c|c|c|c|}
\hline & Consolidation & $1 / 1$ & $2 / 1$ & 5 \\
\hline & Definition of task & $2 / 5$ & $1 / 2$ & 10 \\
\hline & Differentiation & $3 / 5$ & $2 / 3$ & 13 \\
\hline & Introduction & $1 / 0$ & $1 / 3$ & 5 \\
\hline & Learning benefit & $3 / 1$ & $3 / 7$ & 14 \\
\hline & Learning goal & $9 / 9$ & $13 / 8$ & 39 \\
\hline & Lesson planning & $8 / 4$ & $2 / 6$ & 20 \\
\hline & Methods and social forms & $1 / 2$ & $3 / 0$ & 6 \\
\hline Reflecting on subject & $\begin{array}{l}\text { Relationship to everyday } \\
\text { life and relevance }\end{array}$ & $1 / 1$ & $6 / 3$ & 11 \\
\hline & Structure / common theme & $0 / 2$ & $2 / 1$ & 5 \\
\hline & Student orientation & $0 / 1$ & $4 / 0$ & 5 \\
\hline & Teaching materials & $1 / 2$ & $3 / 0$ & 6 \\
\hline & Time management & $4 / 2$ & $0 / 3$ & 9 \\
\hline & Transfer & $0 / 0$ & $1 / 0$ & 1 \\
\hline & Use of media & $3 / 3$ & $1 / 0$ & 7 \\
\hline & Total & $42 / 42$ & $49 / 42$ & 175 \\
\hline & $\begin{array}{l}\text { of which teacher's } \\
\text { perspective }\end{array}$ & $28 / 30$ & $30 / 20$ & 140 \\
\hline & $\begin{array}{l}\text { of which student's } \\
\text { perspective }\end{array}$ & $4 / 6$ & $11 / 15$ & 31 \\
\hline $\begin{array}{l}\text { Reflecting on teaching } \\
\text { and learning action }\end{array}$ & $\begin{array}{l}\text { Disruptions and dealing } \\
\text { with disruptions }\end{array}$ & $3 / 4$ & $5 / 7$ & 19 \\
\hline & Focus on the teacher & $2 / 0$ & $1 / 0$ & 3 \\
\hline & Group mobilization & $3 / 2$ & $3 / 3$ & 11 \\
\hline & Rules & $0 / 0$ & $0 / 1$ & 1 \\
\hline & Student-teacher interaction & $3 / 1$ & $3 / 5$ & 12 \\
\hline & Support/Feedback & $0 / 0$ & $0 / 2$ & 2 \\
\hline & Volume & $1 / 1$ & $0 / 0$ & 2 \\
\hline & Total & $12 / 8$ & $12 / 18$ & 50 \\
\hline & $\begin{array}{l}\text { of which teacher's } \\
\text { perspective }\end{array}$ & $6 / 6$ & $8 / 7$ & 34 \\
\hline & $\begin{array}{l}\text { of which student's } \\
\text { perspective }\end{array}$ & $2 / 3$ & $4 / 8$ & 13 \\
\hline Teacher's demeanour & & $1 / 6$ & $3 / 1$ & 11 \\
\hline
\end{tabular}

\section{Discussion, Conclusion and Acknowledgements}

On the basis of the results, a comparison of the groups reveals specific effects of opportunities for reflection on teaching. However, these results are based on a quasi-experimental design with a small cohort and only a single iteration of the seminar concept. Hence the findings should be systematically verified by follow-up studies with an experimental design. The results should therefore be regarded as an insight into the different effects of reflecting on one's own teaching and that of one's classmates in the course of teacher training. They highlight the potentials of systematically combining reflection on teaching and of closely linking educational sciences and teaching methodologies. These preliminary findings thus supply interesting and highly promising points of departure for further elaboration of the differences between the two forms of reflection.

One insight that should not be neglected is that recognising a personal benefit for one's later professional work is a key factor for creating awareness of the relevance of systematic reflection on teaching. A comparison between the groups confirms that students consistently perceive self-reflection as being personally significant (Niggli, 2002). However, recognising the relevance (for their training) of reflecting on others' teaching leads to positive effects that have a powerful impact on increasing the perceived relevance of reflection. This emphasizes the positive effect of both forms of reflection on the perception of relevance and illustrates the necessity of doing more to specifically encourage recognition of the personal benefit of reflecting on others' teaching. This is particularly significant with respect to the second phase of teacher training, since reflecting on others' teaching (together with reflecting on own teaching) represents a core competence and this course design helps students to experience the personal benefit of - 
as well as the challenges inherent in - analysing actions in the classroom.

An interesting aspect is the findings concerning the perception of the benefits of reflecting on one's own and others' actions in the classroom and its effect on the intention to continue systematically reflecting on teaching in the future. Here the findings suggest that the students recognize specific functional potentials in both forms of reflection. The specific potential of a critically reflective analysis of others' teaching videos lies in the observation and evaluation of other people's classroom actions. Thus, this form of reflection makes a central and indispensable contribution to the internalization of a methodical, controlled procedure and the acquisition of fundamental skills. It seems reasonable to suppose that systematic critically reflective engagement with others' teaching and learning processes $a$ priori helps to establish the personal detachment that is necessary for professional reflection and therefore facilitates a more objective perspective on teaching. Here the potential of systematically combining the units of reflection-on-action based on own and others' teaching becomes apparent. The reflection units on others' teaching, which are performed first, serve as the basis for subsequent reflection processes on own teaching. From the students' perspective, this form of reflection is significant specifically because it allows them to derive alternatives for action, so that its primary purpose is the optimization of own teaching. Thus, this form of reflection seems to be accompanied by higher self-expectations on the part of the students. The findings on the subjective assessments of competence also confirm that this basis for reflection appears to make greater and more complex demands of the students. In contradiction to other studies (Star \& Strickland, 2008; Santaga \& Guarino, 2011) revealing a greater effect on the analysis of own actions, both student groups feel more secure when reflecting others' teaching. This indicates that there is an imbalance between the degree of complexity of the two forms of reflection. It may be that subjective perceptions of the students' own teaching personality have an invasive effect on the reflection process. If so, this challenge can only be met by internalising a methodical, controlled approach; by repeated, systematically encouraged reflection of others' teaching; and with the necessary detachment. Supervision and the use of meta-reflection is required to avoid focusing on subject-specific aspects such as appearance or voice.

Additionally, continual invitations to reflect teaching and learning processes throughout the duration of the seminar appear to contribute towards optimising the ability to identify subjects for reflection. The students in the intervention group appear to be increasingly capable of analysing school teaching and learning processes in a more nuanced and systematic way based on theory and criteria; they are also more skilled at identifying reflection-relevant situations from the various perspectives of relevant actors in the same controlled manner. The conceptual implementation of Schön (1983) proves to be beneficial for systematically integrating reflection units into the curriculum and implementing them in an appropriate, cooperative, and hence interdisciplinary way in order to help optimize the linking of curricular contents from the educational sciences and from teaching methodology. Thus, the drafting of reflection topics with a methodological connotation exhibits clear effects of the interdisciplinary thrust of this course format in the form of the close coupling of educational science and teaching methodology seminars.

\section{References}

Abels, S. (2011). Lehrerinnen und Lehrer als „Reflective Practitioner": Reflexionskompetenz für einen demokratieförderlichen Naturwissenschaftsunterricht. VS Verlag für Sozialwissenschaften. https://doi.org/10.1007/978-3-531-92735-0_4

Artmann, M., Herzmann, P., Hoffmann, M., \& Proske, M. (2013). Wissen über Unterricht - Zur Reflexionskompetenz von Studierenden in der ersten Phase der Lehrerbildung. In A. Gehrmann, B. Kranz, S. Pelzmann, \& A. Reinartz (Eds.), Formation und Transformation der Lehrerbildung: Entwicklungstrends und Forschungsbefunde (pp. 134-150). Bad Heilbrunn: Klinkhardt.

Baumert, J., \& Kunter, M. (2006). Stichwort: Professionelle Kompetenz von Lehrkräften. Zeitschrift für Erziehungswissenschaft, 9(4), 469-520.

Bengtsson, J. (2003). Possibilities and limits of self-reflection in the teaching profession. Studies in Philosophy and Education, 22(3/4), 295-316. https://doi.org/10.1023/A:1022813119743

Borko, H., Jacobs, J., Eiteljorg, E., \& Pittman, M. E. (2008). Video as a tool for fostering productive discussions in mathematics professional development. Teaching and Teacher Education, 24(2), 417-436.

Brouër, B., \& Gläser-Zikuda, M. (2010). Förderung selbstregulativer Fähigkeiten im Kontext selbstorganisierten Lernens. In J. Seifried, E. Wuttke, R. Nickolaus, \& P.F.E. Sloane (Eds.), Lehr-Lern-Forschung in der kaufmännischen Berufsbildung. Ergebnisse und Gestaltungsaufgaben. Zeitschrift für Berufs- und Wirtschaftspädagogik Beiheft Bd. 23 (pp. 123-136). Stuttgart: Franz Steiner Verlag. 
Bromme, R., \& Haag, L. (2008). Forschung zur Lehrerpersönlichkeit. In W. Helsper, \& J. Böhme (Eds.), Handbuch der Schulforschung (pp. 803-819). https://doi.org/10.1007/978-3-531-91095-6_32

Copeland, W. D., Birmingham, C., De la Cruz, E., \& Lewin, B. (1993). The Reflective Practitioner in Teaching: Towards a Research Agenda. Teaching and Teacher Education, 9(4), 347-359. https://doi.org/10.1016/0742-051X(93)90002-X

Day, C. (1993). Reflection: a necessary but not sufficient condition for professional development. British Educational Research Journal, 19(1), 83-93. https://doi.org/10.1080/0141192930190107

Fat'hi, J., \& Behzadpour, F. (2011). Beyond Method: The Rise of Reflective Teaching. International Journal of English Linguistics, 1(2), 241-251. https://doi.org/10.5539/ijel.v1n2p241

Feindt, A. (2007). Studentische Forschung im Lehramtsstudium. Eine fallrekonstruktive Untersuchung studienbiografischer Verläufe und studentischer Forschungspraxen: Studien zur Bildungsgangforschung. Opladen: Budrich.

Felten, R. von (2005). Lernen im reflexiven Praktikum: Eine vergleichende Untersuchung. Internationale Hochschulschriften, 441. Münster: Waxmann.

Gabriel-Busse, K., Groß-Mlynek, L., Feldhoff, T., \& Harring, M. (2020). Eine Unterrichtssequenz - unterschiedliche Einschätzungen: Analyse videografierter Unterrichtssequenzen als Bestandteil einer evidenzbasierten Lehrer/innenausbildung. In: I. Gogolin, B., Hannover, \& A. Scheunpflug (Eds.), Evidenzbasierung in der Lehrkräftebildung. Zeitschrift für Erziehungswissenschaft (ZfE), Band 4, (pp. 291-314). Wiesbaden: Springer.

Hatton, N., \& Smith, D. (1995). Reflection in teacher education: Towards definition and implementation. Teaching and Teacher Education, 11(1), 33-49.

Helmke, A. (2012). Unterrichtsqualität und Lehrerprofessionalität. Diagnose, Evaluation und Verbesserung des Unterrichts. Seelze-Velber: Kallmeyer Klett.

Herzmann, P., Artmann M., \& Wichelmann, E. (2017). Theoriegeleitete Reflexionen videographierten Unterrichts. Eine Typologie studentischer Perspektiven auf universitäre Theorie-Praxis-Bezüge. In C. Berndt, T. Häcker, \& T. Leonhard. (Eds.), Reflexive Lehrerbildung revisited. Traditionen - Zugänge - Perspektiven (pp. 176-189). Bad Heilbrunn: Verlag Julius Klinkhardt.

Hoffart, E. (2015). Aus einem anderen Blickwinkel - Lehramtsstudierende reflektieren im Seminar "MatheWerkstatt". In Kompetenzzentrum der Universität Siegen (Eds.), Die Idee dahinter...Aspekte zur Gestaltung lernreicher Lehre, Werkstattbericht: Hochschuldidaktik 4 (pp. 47-62). Siegen: UniPrint.

Hoffart, E., \& Helmerich, M. (2017). „In der Situation ist mir das gar nicht aufgefallen!“ Reflexionsanlässe in der Lehrerbildung als Bindeglied zwischen Theorie und Praxis. In U. Kortenkamp, \& A. Kuzle (Eds.), Beiträge zum Mathematikunterricht (pp. 433-436). Münster: WTM.

Hugener, I., Pauli, C., \& Reusser, K. (2007). Inszenierungsmuster, kognitive Aktivierung und Leistung im Mathematikunterricht. Analysen aus der deutsch-schweizerischen Videostudie. In S. Lemmermöhle, M. Rothgangel, S. Bögenholz, M. Hasselhorn, \& R. Watermann (Eds.), Professionell Lehren - Erfolgreich Lernen (pp. 109-121). Münster: Waxmann.

Kahlau, J., \& Tietjen, C. (2018). Reflexive Begleitung von Studien-Praxis-Projekten und die Förderung von Reflexivität in (alternativen) Praxisphasen. Herausforderung Lehrer_innenbildung-Zeitschrift zur Konzeption, Gestaltung und Diskussion, 1(2), 126-141. https://doi.org/10.4119/UNIBI/hlz-63

Klieme, E., Lipowski, F., Rakoczy, K., \& N. Ratzka (2006). Qualitätsdimensionen und Wirksamkeit von Mathematikunterricht: Theoretische Grundlagen und ausgewählte Ergebnisse des Projekts "Pythagoras". In M. Prenzel, \& L. Allolio-Näcke (Eds.), Untersuchungen zur Bildungsqualität von Schule. Abschlussbericht des DFG-Schwerpunktprogramms (pp. 127-146). Münster, Westfalen u.a.: Waxmann.

Klieme, E., \& Rakoczy, K. (2008). Empirische Unterrichtsforschung und Fachdidaktik. Outcome-orientierte Messung und Prozessqualität des Unterrichts. Zeitschrift für Pädagogik, 54(2), 222-237.

König, J. (2015). Measuring classroom management expertise (CME) of teachers: a video- based assessment approach and statistical results. Cogent Education, 2(1). https://doi.org/10.1080/2331186X.2014.991178

Kramer, C., König, J., Kaiser, G., Ligtvoet, R., \& Blömeke, S. (2017). Der Einsatz von Unterrichtsvideos in der universitären Ausbildung: Zur Wirksamkeit video- und transkriptgestützter Seminare zur Klassenführung auf 
pädagogisches Wissen und situationsspezifische Fähigkeiten angehender Lehrkräfte. Zeitschrift für Erziehungswissenschaft, 20(1), 137-164. https://doi.org/10.1007/s11618-017-0732-8

Krammer, K., \& Reusser, K. (2005). Unterrichtsvideos als Medium der Aus- und Weiterbildung von Lehrpersonen. Beiträge zur Lehrerbildung, 23(1), 35-50.

Krull, E., Oras, K., \& Sisak, S. (2007). Differences in teachers' comments on classroom events as indicators of their professional development. Teaching and Teacher Education, 23(7), 1038-1050. https://doi.org/10.1016/j.tate.2006.02.001

Kunter, M., \& Trautwein, U. (2013). Psychologie des Unterrichts. Paderborn: Ferdinand Schöningh Verlag.

Leijen, Ä., Lam, I., Wildschut, L., Simons, P., \& Robert-Jan, P. (2009). Difficulties teachers report about students' reflection: lesson learned from dance education. Teaching in higher Education, 14(3), 315-326.

Leitch, R., \& Day, C. (2000). Reflection and professional knowledge: A conceptual framework. Educational Action Research, 8(1), 179-193. https://doi.org/10.1080/09650790000200108

Leonhard, T. (2013): Portfolioarbeit zwischen Reflexion und Leistungsbewertung. Empirische Befunde zur Messbarkeit von Reflexionskompetenz. In B. Koch-Priewe, T. Leonhard, A. Pineker, \& J. C. Störtländer (Eds.), Portfolio in der LehrerInnenbildung. Konzepte und empirische Befunde (pp. 180-192). Bad Heilbrunn: Klinkhardt.

Leutner-Ramme, S. (2000). Schüler vor der Kamera: Es war interessant gefilmt zu werden - aber sonst war es gut wie immer. In T. Knauth, S. Leutner-Ramme, \& W. Weiße (Eds.), Religionsunterricht aus Schülerperspektive (pp.231-250). Münster u.a.: Waxmann.

Lipowsky, F., Rakoczy, K., Pauli, C., Drollinger-Vetter, B., Klieme, E., \& Reusser, K. (2009). Quality of geometry instruction and its short-term impact on students' understanding of the Pythagorean Theorem. Learning and Instruction, 19(6), 527-537.

Louden, W., Wallace, J., \& Groves, R. (2001). Spinning a Web (Case) Around Professional Standards. Capturing the Complexity of Science Teaching. Research in Science and Education, 31(2), 227-244. https://doi.org/10.1023/A:1013130126345

Loughran, J. (2002). Effective Reflective Practice: In Search of Meaning in Learning about Teaching. Journal of Teacher Education, 53(1), 33-43. https://doi.org/10.1177/0022487102053001004

Mayring, P. (2015). Qualitative Inhaltsanalyse. Grundlagen und Techniken. Weinheim: Beltz.

Meyer, H. (2003). Skizze eines Stufenmodells zur Analyse von Forschungskompetenz. In A. Obolenski, \& H. Meyer (Eds.), Forschendes Lernen. Theorie und Praxis einer professionellen LehrerInnenausbildung (pp. 99-115). Bad Heilbrunn/OBB.: Klinkhardt.

Mühlhausen, U. (2006). Unterricht lernen mit Gespür: Szenarien für eine multimedial gestützte Analyse und Reflexion von Unterricht. Baltmannsweiler: Schneider.

Niggli, A. (2002). Welche Komponenten reflexiver beruflicher Entwicklung interessieren angehende Lehrerinnen und Lehrer? Faktorenstruktur eines Fragebogens und erste empirische Ergebnisse. Revue suisse des sciences de l'education, 26(2), 343-364.

Petko, D., Waldis, M., Oauli, C., \& Reusser, K. (2003). Methodologische Überlegungen zur videogestützten Forschung in der Mathematikdidaktik. Ansätze der TIMSS 1999 Video Studie und ihrer schweizerischen Erweiterung. ZDM (Zentralblatt für Didaktik der Mathematik), 35(6), 265-280.

Plöger, W. (2006). Was ist Kompetenz?- eine theoretische Skizze. In W. Plöger (Eds.), Was müssen Lehrerinnen und Lehrer können? (pp. 17-58). Paderborn: Schöningh.

Reinmann, G. (2015). Heterogenität und forschendes Lernen: Hochschuldidaktische Möglichkeiten und Grenzen. In B. Klages, M. Bonillo, S. Reinders, \& A. Bohmeyer (Eds.), Gestaltungsraum Hochschullehre. Potenziale nicht-traditionell Studierender nutzen (pp. 121-137). Opladen: Budrich.

Roters, B. (2012). Professionalisierung durch Reflexion in der Lehrerbildung. Eine empirische Studie an einer deutschen und einer US-amerikanischen Universität. Münster: Waxmann.

Santagata, R., \& Yeh, C. (2014). Learning to teach mathematics and to analyze teaching effectiveness: evidence from a video- and practice-based approach. Journal of Mathematics Teacher Education, 17, 491-514. 
Santaga, R., \& Guarino, J. (2011). Using video to teach future teachers to learn from teaching. ZDM - The International Journal of Mathematics Education, 43(1), 133-145. https://doi.org/10.1007/s11858-010-0292-3

Sato, M., Akita, K., \& Iwawaka, N. (1993). Practical Thinking Styles of Teachers: A Comparative Study of Expert and Novice Thought Processes and Its Implications for Rethinking Teacher Education in Japan. Peabody Journal of Education, 68(4), 100-110. https://doi.org/10.1080/01619569309538745

Schön, D. A. (1983). The reflective practitioner. How professionals think in action. New York: Basic Books.

Schwindt, K. (2008). Lehrpersonen betrachten Unterricht: Kriterien für die kompetente Unterrichtswahrnehmung. Empirische Erziehungswissenschaft. Münster: Waxmann.

Seidel, T., \& Prenzel, M. (2007). Erfassung pädagogisch-psychologischer Kompetenzen mit Videosequenzen. Zeitschrift für Erziehungswissenschaft, 10(8), 201-216.

Seidel, T., Blomberg, G., \& Stürmer, K. (2010). "Observer" - Validierung eines videobasierten Instruments zur Erfassung der professionellen Wahrnehmung von Unterricht. Projekt OBSERVE. In E. Klieme, D. Leutner, \& M. Kenk (Eds.), Kompetenzmodellierung. Zwischenbilanz des DFG-Schwerpunktprogramms und Perspektiven des Forschungsansatzes. 56. Beiheft der Zeitschrift für Pädagogik (pp. 296-306). Weinheim: Beltz.

Sherin, M. G., \& Han, S. Y. (2004). Teacher learning in the context of a video club. Teaching and Teacher Education, 20(2), 163-183. https://doi.org/10.1016/j.tate.2003.08.001

Snyder, D. W. (2011). Preparing for Teaching through Reflection. Music Educators Journal, 97(3), 56-60. https://doi.org/10.1177/0027432111399348

Star, J. R., \& Strickland, S. K. (2008). Learning to observe: using video to improve preservice mathematics teachers' ability to notice. Journal of Mathematics Teacher Education, 11(2), 107-125. https://doi.org/10.1007/s10857-007-9063-7

Tulodziecki, G., Herzig, B., \& Blömeke, S. (2017). Gestaltung von Unterricht: Eine Einführung in die Didaktik. Bad Heilbrunn: Klinkhardt.

Van Es, E. A., \& Sherin, M. G. (2008). Mathematics teachers' "learning to notice" in the context of video club. Teaching and Teacher Education, 24(2), 244-276. https://doi.org/10.1016/j.tate.2006.11.005

Vogel, R. (2013). Portfolioarbeit als Ort der Selbstreflexion im Lehramtsstudium (am Beispiel des Fachs Mathematik). In B. Koch-Priewe, T. Leonhard, A. Pineker, \& J. C. Störtländer (Eds.), Portfolio in der LehrerInnenbildung. Konzepte und empirische Befunde (pp. 226-236). Bad Heilbrunn: Klinkhardt.

Wehner, F., \& Weber, N. (2018). Erfassung der Reflexionskompetenz bei Lehramtsstudierenden anhand von Fallvignetten. In S. Miller, B. Holler-Nowitzki, B. Kottmann, S. Lesemann, B. Letmathe-Henkel, N. Meyer, R. Schroeder, \& K. Velten (Eds.), Profession und Disziplin. Grundschulpädagogik im Diskurs (pp. 270-275). https://doi.org/10.1007/978-3-658-13502-7

Wirtz, M., \& Caspar, F. (2002). Beurteilerübereinstimmung und Beurteilerreliabilität. Göttingen: Hogrefe Verlag.

Zeichner, K. M., \& Liston, D. P. (1985). Varieties of discourse in supervisory conferences. Teaching and Teacher Education, 1(2), 155-174. htttps://doi.org/10.1016/0742-051X(85)90013-7

Zeichner, K. M., \& Liston, D. P. (1987). Teaching student teachers to reflect. Harvard Educational Review, 57(1), 23-49. https://doi.org/10.17763/haer.57.1.j18v7162275t1w3w

\section{Notes}

Note 1. In Germany, teacher training takes place in three phases: The first phase focuses on teaching theory at universities. In the second phase, the training is completed in the school practice and the third phase relates to the further training of teachers.

Note 2. Currently we are cooperating with these six subject didactics. In the future, the project will be extended to other subjects like Mathematics, physical education or Geography.

Note 3. The dimension of cognitive activation refers to the intellectual content of demands in the classroom and is understood as stimulation to a deeper mental engagement with the subject matter at an optimal level for the learners (Klieme \& Rakozcy, 2008; Lipowsky et al., 2009). This is achieved through a complex task by activating prior knowledge and encouraging learners to contribute, justify and compare their own thoughts, interpretations and 
solutions as well as to relate new things to existing knowledge (cf. Hugener et al., 2007; Klieme \& Reusser, 2003).

Note 4. The theoretical basis of this paper is supplied by the model of teacher professionalism building on the concept of Baumert and Kuntner (2006).

Note 5. The project discussed here is based on teaching videos, as this medium offers the advantage of permitting repeated reflection on classroom actions by different people from different perspectives and independently of time and place. The necessary preconditions are: a constructive approach to teaching videos; the separation of observation and interpretation; and guidance and supervision for expressing the strengths and weakness of the teaching situation with the goal of always analysing the intent and assumed effect of the teaching and learning actions (Krammer \& Reusser, 2005).

Note 6 . The potentials of video-based reflection lie both in its practical relevance and closeness to action (preserving complexity) and simultaneously in the scope it offers for observing authentic teaching situations repeatedly, from different perspectives, and independently of place and time (reducing complexity). The audio and video recording of the lessons is visible to all actors with the permission of the school and exclusively with their consent and provided that all actors filmed, such as teachers, but also the parents of the students give their consent.In addition, studies have shown that if the setting is kept as non-invasive as possible, behaviour normalises after a certain period of time or there is not much difference in pupil behaviour compared to a normal lesson (e.g. Leutner-Ramme, 2000; Petko, Waldis, Oauli \& Reusser, 2003).

Note 7. Students and pupils are fully aware of being video-taped throughout the day. Before the lab day can take place, the written consent of all participants, including the parents, is obtained. So far there were no issues with parental permissions.

Note 8. Because of its purpose, the questionnaire also includes other subject fields, such as self-efficacy and perception of the event, which will be used for further research projects.

Note 9. This scale consists of the items (1) I intend to continue observing my actions in the classroom with professional detachment in future; (2) I intend to continue evaluating my actions in the classroom with professional detachment in future; (3) I intend to continue learning from my own actions in the classroom and applying these insights to subsequent action situations; (4) I intend to continue observing others' actions in the classroom with professional detachment in future; (5) I intend to continue evaluating others' actions in the classroom with professional detachment in future; (6) I intend to continue learning from others' actions in the classroom and applying these insights to subsequent action situations.

Note 10. The scale for reflection-on-action with respect to own actions in the classroom consists of the following three items: (1) How would you rate your competence to observe the effects of your own actions in the classroom with professional detachment? (2) How would you rate your competence to critically evaluate the effects of your own actions in the classroom with professional detachment? (3) How would you rate your competence to learn from your own actions in the classroom and adapt your performance in subsequent situations? Correspondingly, the scale for reflection-on-action with respect to others' actions in the classroom consists of the following three items: (1) How would you rate your competence to observe the effects of others' actions in the classroom with professional detachment? (2) How would you rate your competence to critically evaluate the effects of others' actions in the classroom with professional detachment? (3) How would you rate your competence to learn from others' actions in the classroom and transfer these insights to future action situations?

\section{Copyrights}

Copyright for this article is retained by the author(s), with first publication rights granted to the journal.

This is an open-access article distributed under the terms and conditions of the Creative Commons Attribution license (http://creativecommons.org/licenses/by/4.0/). 